Geosci. Model Dev. Discuss., https://doi.org/10.5194/gmd-2019-65

Manuscript under review for journal Geosci. Model Dev.

Discussion started: 6 May 2019

(c) Author(s) 2019. CC BY 4.0 License.

\title{
Evaluation of Unified Model Rainfall Forecasts over the Western Ghats and North East states of India
}

\author{
Kuldeep Sharma ${ }^{1}$, Sushant Kumar $^{1}$, Raghavendra Ashrit ${ }^{1}$, Sean Milton ${ }^{2}$, Ashis K. Mitra ${ }^{1}$ and \\ Ekkattil N. Rajagopal ${ }^{1}$ \\ ${ }^{1}$ National Centre for Medium Range Weather Forecasting, A-50, Sector-62, Noida 201309 \\ ${ }^{2}$ Met Office, FitzRoy Road, Exeter Devon, EX1 3PB, United Kingdom \\ Correspondence to: Kuldeep Sharma (kuldeep@ncmrwf.gov.in)
}

\begin{abstract}
Prediction of heavy rains associated with orography is still a challenge, even for the most advanced state-of-art high-resolution Numerical Weather Prediction (NWP) modeling systems.

The aim of this study is to evaluate the performance of UK Met Office Unified Model (UM) in predicting heavy and very heavy rainfall exceeding $80^{\text {th }}$ and $90^{\text {th }}$ percentiles which occurs mainly due to the forced ascent of air parcels over the mountainous regions of the Western Ghats (WGs) and North East (NE) - states of India during the monsoon seasons of 2007 to 2018. Apart from the major upgrades in the dynamical core of UM from New Dynamics (ND) to Even Newer
\end{abstract} Dynamics for General Atmospheric Modeling of the environment (ENDGame), the horizontal resolution of the model has been increased from $40 \mathrm{~km}$ and 50 vertical levels in 2007 to $10 \mathrm{~km}$ and 70 vertical levels in 2018. In general, it is expected that the prediction of heavy rainfall events improves with increased horizontal resolution of the model. The evaluation based on verification metrics, including Probability of Detection (POD), False Alarm Ratio (FAR), Frequency Bias (Bias) and Critical Success Index (CSI), indicate that model rainfall forecasts from 2007 to 2018 have improved from 0.29 to 0.38 (CSI), 0.45 to 0.55 (POD) and 0.55 to 0.45 in the case of FAR over WGs for rainfall exceeding the $80^{\text {th }}$ percentile (CAT-1) in the Day-1 forecast. Additionally, the Symmetric Extremal Dependence Index (SEDI) is also used with special emphasis on verification of extreme and rare events. SEDI also shows an improvement 
Geosci. Model Dev. Discuss., https://doi.org/10.5194/gmd-2019-65

Manuscript under review for journal Geosci. Model Dev.

Discussion started: 6 May 2019

(c) Author(s) 2019. CC BY 4.0 License.

from 0.47 to 0.62 and 0.16 to 0.41 over WGs and NE-states during the period of study, suggesting an improved skill of predicting heavy rains over the mountains. It has also been found that the improvement is consistent and comparatively higher over WGs than NE-states.

Key Words: Orographic rain, Unified Model, Categorical verification, extreme rain, rainfall forecast, NWP

\section{Introduction}

Orography is the primary cause of up-lift of air parcels together with convectively driven rainfall in mountainous regions (Flynn et al., 2017). The spells of heavy orographic rainfall may induce landslides and flash flooding which lead to tremendous damage to the lives, property, infrastructure, environment and local economy. One of the most tragic landslides occurred in Kedarnath (Uttarkhand, India) in 2013 which led to more than 1000 deaths and 61000 stranded (Dube et al., 2014). During the last decade, the number of landslide incidences over India has increased and it contributes $16 \%$ of all rainfall-triggered landslides in the global dataset (Froude and Petley, 2018). The accurate prediction of this heavy rainfall with enough lead time over mountains can help in mitigation and precautions towards rainfall induced disasters. Forecasting of this orographically induced heavy rainfall is one of the most challenging problems for numerical weather prediction (NWP) models. This is because of the complexity of the meteorological phenomena occurring over the orographic regions and the difficulty of obtaining detailed and precise observational data sets. (Smith et al., 1997, Mecklenburg et al., 2000, Lin et. al, 2001). This leads to the poor representation initial conditions required to run the NWP model (Panziera et al., 2011). However, there is a significant improvement in the forecasting skill of

47 NWP models in recent times. Some of these improvements can be attributed to the increased horizontal and vertical resolutions as well as improved physics parameterization schemes 
Geosci. Model Dev. Discuss., https://doi.org/10.5194/gmd-2019-65

Manuscript under review for journal Geosci. Model Dev.

Discussion started: 6 May 2019

(c) Author(s) 2019. CC BY 4.0 License.

(Sharma et. al. 2017), while major credit to the substantial improvements in weather forecasting goes to the sophisticated data assimilation systems which utilize the satellite data.

51 The Indian subcontinent is highly vulnerable to heavy rainfall events. Most of the heavy and

52 extreme rainfall events occur during the southwest monsoon season (June to September, JJAS).

53 Western Ghats (WGs), North-Eastern (NE) states (Assam, Meghalaya, Mizoram, Arunachal

54 Pradesh, Sikkim, Manipur and Tripura) of India and central India are the most prominent regions

55 of heavy rainfall (Pattanaik and Rajeevan 2010). Central India receives rainfall mainly due to the

56 Low Pressure Systems (LPS) and Monsoon Depressions (MD) that form over the Bay of Bengal

57 (BoB) and move towards the west north-westward during JJAS (Goswami et al 2006; Sikka, 2006; Ajaymohan et al., 2010; Krishnamurthy and Ajaymohan, 2010) and only on very few occasions do these LPS and MD's move northwards to produce a significant amount of rainfall over the NE states. The WGs and the NE states of India are regions characterized by steep orography and the heavy rainfall in these regions are often due to forced ascent of air parcels over the mountains. These two mountainous regions of India have the highest annual rainfall (Rao, 1976, Parthasarathy et al., 1995). The WGs are aligned north-south along the western coast of India extending from Gujarat to Kerala with a narrow zonal width and steep rising western face with the highest peak $(2.6 \mathrm{Km})$ named Anamudi and located in Kerala. The north-east region is dominated by the Eastern Himalayan mountain range. Geographically, two-thirds of the area is hilly terrain interspersed with valleys and plains. The mean summer monsoon rainfall over NE-States is $\sim 151.3 \mathrm{~cm}$ which is much larger than the all India average $(86.5 \mathrm{~cm})$ (Parthasarathy et al., 1995) making it a potential zone for hydropower. The WGs plays a dominant role in modulating the southwest monsoon, which in turn modulates the regional climate (Gunnell 1997), as its first encounter on landfall over India is with these 
Geosci. Model Dev. Discuss., https://doi.org/10.5194/gmd-2019-65

Manuscript under review for journal Geosci. Model Dev.

Discussion started: 6 May 2019

(c) Author(s) 2019. CC BY 4.0 License.

mountain chains. Evaluation of the operational Unified Model (UM) rainfall forecast over India, using multiple monsoon seasons, is documented in two recent studies. Kuldeep et al, (2017) report improved skill of predicting heavy rainfall ( $>2$ and $>5 \mathrm{~cm} /$ day ) over India (Core Monsoon Zone: $18-28 \mathrm{~N}, 68-88 \mathrm{E})$. In another study, Kuldeep et al (2019) document the spatial verification of rainfall using Contiguous Rain Areas (CRA) method over different regions of India. Here, evaluation of operational UM rainfall forecasts is focused on mountainous regions of India (over WGs and NE-states). The study period extends over twelve monsoon seasons (2007-2018). Evaluation is carried out with special emphasis on heavy rainfall. Unlike earlier studies, the verification is based on quintile based rainfall thresholds rather than absolute rainfall amounts. During 2007-18, there has been considerable interannual variability in the monsoon. India Meteorological Department (IMD) reports show that during 2007,2008,2010 and 2011-13, monsoon rainfall was above normal, while it was below normal during 2009 and 2014-18. The rainfall events exceeding two thresholds, the $80^{\text {th }}$ (hereafter CAT-1) and $90^{\text {th }}$ percentiles (hereafter CAT-2) have been chosen to verify the forecast produced by the UM. For verification based on percentiles the fraction of events classified as 'yes' are identical for different locations or times of the year (Hamill and Juras, 2006), regardless of whether the climatological means and variances are large or small. The rationale for choosing these rainfall thresholds of CAT-1 and CAT-2 based on percentiles is discussed in section 4 .

\section{Data and Methodology}

\subsection{Observed Data}

The availability of daily rainfall data for long climatological periods is crucial for understanding the components and processes related to the Indian monsoon. Daily rainfall associated with orography, low-pressure systems and monsoon depressions contribute significantly to the total 
Geosci. Model Dev. Discuss., https://doi.org/10.5194/gmd-2019-65

Manuscript under review for journal Geosci. Model Dev.

Discussion started: 6 May 2019

(c) Author(s) 2019. CC BY 4.0 License.

seasonal rainfall. Orography plays a crucial role; the validation of numerical models requires accurate rainfall information over land and adjoining seas (Mitra et al., 2013). The major data sources of the rainfall are rain gauge, radar and satellite estimates (Ebert et al., 2003; Mitra et al., 2009). Although the rain gauge network is not evenly spread in space and often very sparse over unpopulated regions, particularly in mountainous areas, rainfall measurements from rain gauges remain the most reliable data sources over land as they have good time resolution and provide an accurate estimate of ground truth at a particular location. The improved representation of heavy rainfall events due to an enhanced rain gauge network over WGs and NE-states have been recently reported in Pai et al. (2014).

The period of the observed dataset used in this study is the monsoon season (JJAS) from 2007 to 2018. The two domains selected for the study are WGs $\left(72-78^{\circ} \mathrm{E}, 8-23^{\circ} \mathrm{N}\right)$ and NE- states $(88-$ $\left.100^{\circ} \mathrm{E}, 21-30^{\circ} \mathrm{N}\right)$. The verification has been carried out over Indian land points only.

The gridded daily rainfall data set obtained from IMD for the period 2007-2011 is used in the present study. The geographical distribution of IMD's rain gauges on any typical day over India during the monsoon is shown in Figure 1(a). The boxes (WGs and NE-states) represent the domains chosen for this study. The zoomed plots of WGs and NE-states are also displayed in Figure 1(b) and (c). The number of grid points (land only) over WGs and NE-states used in the present study are 475 and 403 respectively. The number of rain gauge stations on any typical day over WG and NE-states are 796 and 132 respectively. The Shepard interpolation technique (1968), also discussed in Rajeevan et al. (2006), has been adopted for the gridding this rainfall data. During the monsoon seasons of 2012-2018, NCMRWF-IMD (National Centre for Medium Range Weather Forecasting - Indian Meteorological Department) merged satellite-rainfall analyses have been used. For the monsoon seasons of 2012-15, NCMRWF-IMD rainfall data are 
Geosci. Model Dev. Discuss., https://doi.org/10.5194/gmd-2019-65

Manuscript under review for journal Geosci. Model Dev.

Discussion started: 6 May 2019

(c) Author(s) 2019. CC BY 4.0 License.

the merged product of near-real-time Tropical Rainfall Measuring Mission Multi-satellite Precipitation Analysis (TMPA)-3B42 and rain gauge data from the India Meteorological Department (IMD) using an objective analysis scheme (NMSG; Mitra et al. 2009). For the period 2016-2018, the rainfall estimates from Global Precipitation Measurement (GPM) satellite have been used to merge with IMD's rain gauge stations to characterize the best rainfall estimates over the Indian region. The spatial resolution of the data is at $0.5^{\circ} \times 0.5^{\circ}$. However, the spatial resolution of rainfall data from the monsoon season of 2016 onwards is available originally at a horizontal resolution of $0.25^{\circ}$, but we have interpolated this data set using a bilinear interpolation technique at a spatial resolution of $0.5^{\circ}$ to make a uniform rainfall data series throughout the study. This merged data set represents the Indian monsoon rainfall more realistically and is superior to other available rainfall data sets over the Indian monsoon region because it uses additional local rain gauge observations (Mitra et al. 2013), and consequently provides a better baseline for NWP model validation and monsoon model development.

\subsection{Description of the NWP Modelling System and Forecast Dataset} seamless prediction of weather and climate systems (Davies et al. 2005; Brown et al. 2012, Wood et al. 2014; Met Office 2014). This 'seamless' prediction system implies that the same model with slightly different configurations (e.g. resolution) is used across a range of temporal and spatial scales, with configurations traceable to each other and designed to best represent the processes which have most influence on the timescale of interest (Martin et al. 2010). The rainfall forecast from the Met Office operational medium range (1-7 day) global model configuration is used in this study. The Unified Model (UM) is in a process of continuous development, taking advantage of improved understanding of atmospheric processes and steadily 
Geosci. Model Dev. Discuss., https://doi.org/10.5194/gmd-2019-65

Manuscript under review for journal Geosci. Model Dev.

Discussion started: 6 May 2019

(c) Author(s) 2019. CC BY 4.0 License.

increasing supercomputer power. The atmospheric component of the UM is based on nonhydrostatic dynamics with semi-Lagrangian advection and semi-implicit time stepping. It is a grid point model with the ability to run with a rotated pole and variable horizontal grid. A number of sub-grid scale processes are represented, including convection (Gregory and Rowntree 1990; Gregory and Allen 1991; Grant 2001), boundary layer turbulence (Brown et al., 2007), radiation (Edwards and Slingo, 1996), cloud microphysics and orographic drag (Webster et al.2003). The model is initialized using a state of the art global four-dimensional variation (4DVAR; Rawlins et al. 2007) data assimilation technique. The year to year important changes and upgrades during 2007-2018 in the model configuration are briefly listed in Table 1. During 2007-2018, the horizontal and vertical resolution of the global NWP configuration improved from about $40 \mathrm{~km}$ and 50 levels in 2007 to about $10 \mathrm{~km}$ and 70 levels in 2018. A major upgrade in the dynamical core happened in July 2014. In 2002 the "New Dynamics" upgrade was implemented (Davies et al., 2005). After a decade, in July 2014, the new dynamical core named "ENDgame" was implemented operationally at Met Office UM (Wood et al. 2014; Met Office2014). The "ENDGame" has an advantage over its predecessor "New Dynamics" in terms of increases in atmospheric variability. This is manifest in improved details and intensity of large-scale storms in weather forecasts, which arises from the use of less artificial damping in the ENDGame formulation (Met Office 2014). In addition to horizontal resolution and dynamical core, a number of other key changes were introduced. One is the change of resolution of data assimilation component from approximately $60 \mathrm{~km}(\mathrm{~N} 216)$ to $40 \mathrm{~km}(\mathrm{~N} 320)$. There is a change to model physics which includes an increase in entrainment rate in deep convection and improvements to several other physical parameterization schemes. The complete package is called Global Atmosphere 6.0 (GA6) and more details are available in Walters et al. (2017). 
Geosci. Model Dev. Discuss., https://doi.org/10.5194/gmd-2019-65

Manuscript under review for journal Geosci. Model Dev.

Discussion started: 6 May 2019

(c) Author(s) 2019. CC BY 4.0 License.

Daily rainfall forecast up to Day-3, produced by the global operational UM used for NWP have been evaluated over two mountainous regions of WGs and NE-states. The rainfall forecast is also interpolated at $0.5^{\circ} \times 0.5^{\circ}$ for direct comparison with the observed rainfall. The evaluation has been restricted only over the land points to focus the model performance over land orographic regions.

\section{3. Verification Approach}

170 Traditional verification methods such as a categorical approach are generally based on rainfall

171 accumulation thresholds or rainfall ranges. This approach is used by most of the operational NWP centers to evaluate the rainfall forecast (Airey and Hulme, 1995; Wilson, 2000). When we consider a fixed rainfall threshold or range, it is observed that the verification scores drop quite rapidly, particularly at high threshold or range (Ashrit et al., 2015). In general, the rainfall distribution over different regions are inhomogeneous due to different precipitation mechanisms. As discussed earlier about the occurrence of rainfall at different regions of India, it is very difficult to choose the same threshold of absolute quantities to evaluate the skill of a model (in different regions). For instance, a rainfall threshold of $5 \mathrm{~cm} /$ day over the core monsoon Zone (CMZ) can be considered as heavy rain (Sharma et al., 2017), which may not be the case over the WGs and NE-states. There is a need to revisit rainfall verification based on accumulation thresholds or ranges. To overcome this issue, Robert (2008) and Zhu et al. (2015) have used rainfall verification based on percentiles rather than the accumulation thresholds. The purpose of choosing the percentiles over accumulation thresholds is to remove the impact of any biases and climatological frequencies for that region (Robert 2008; Zhu et al., 2002; Buizza et al., 2003). In the present study, daily rainfall forecasts have been verified using the standard categorical 
Geosci. Model Dev. Discuss., https://doi.org/10.5194/gmd-2019-65

Manuscript under review for journal Geosci. Model Dev.

Discussion started: 6 May 2019

(c) Author(s) 2019. CC BY 4.0 License.

scores, for percentile-based thresholds. A categorical approach is based on the $2 \times 2$ contingency table (Table 2) evaluating for different thresholds.

To evaluate the skill of the NWP forecast system, verification metrics focus on the correspondence between the observation and forecast (Murphy, 1993). The 24-hour rainfall exceeding $80^{\text {th }}$ and $90^{\text {th }}$ percentiles thresholds are events of interest in the present study. The percentiles are computed over the entire period (2007-2018). Figure S1 (a) and (b) show $80^{\text {th }}$ and $90^{\text {th }}$ percentiles rainfall in the observations. Similarly, the bottom panels, Figure S1 (c) and (d) show $80^{\text {th }}$ and $90^{\text {th }}$ percentiles rainfall in the forecasts. These are the reference thresholds for the evaluation. A hit is considered when prediction of an event matches the observation on a grid point, while an event on a grid point predicted but not observed, we denote as a false alarm (b). A miss (c) occurs when an event is not predicted but is actually observed. Finally, correct rejection (d) is when an event doesn't occur and the model doesn't predict it. These four variables are the components of the $2 \times 2$ contingency table and are displayed in Table 2. BIAS, Probability of Detection (POD), False Alarm Ratio (FAR), Critical Success Index (CSI) and Symmetric Extremal Dependence Index (SEDI) are some of the metrics used in this study. POD is defined as ratio of number of correct forecasts (a) to the number of observed events $(a+c)$ while FAR is the ratio of number of false alarms (b) to the number of forecasts made $(a+b)$. The ratio of number of hits (a) to all events either forecast or observed $(a+b+c)$ is known as CSI. All three scores range from 0 to 1 , with 1 being a perfect score in case of POD as well as CSI and 0 for perfect FAR. The Bias Score is calculated as the ratio of the number of predicted events $(a+b)$ to the observed events $(a+c)$ exceeding a given threshold (Donaldson et al., 1975). The Bias Score ranges from 0 to infinity with a value of 1 meaning perfect forecast. The Bias Score can help in identifying whether the forecast system has a tendency to underpredict 
Geosci. Model Dev. Discuss., https://doi.org/10.5194/gmd-2019-65

Manuscript under review for journal Geosci. Model Dev.

Discussion started: 6 May 2019

(c) Author(s) 2019. CC BY 4.0 License.

$($ BIAS $<1)$ or overpredict $($ BIAS $>1)$ events. Since the Bias Score does not provide any information about the forecast accuracy, it is generally evaluated in conjunction with another verification score such as Critical Success Index (CSI) or Equitable Threat Score (ETS) (Ebert et al 2003). The detailed formulae of these metrics are displayed in Table 3 and a detailed description can be found in Wilks (2011) and Jolliffe and Stephenson (2012). These verification metrics have been computed for twelve monsoon seasons for rainfall exceeding $80^{\text {th }}$ (CAT-1) and $90^{\text {th }}$ percentiles (CAT-2) over WGs and NE-states.

\section{Results and Discussion}

\subsection{Evaluation of Forecast Rain during recent years}

The mean seasonal rainfall obtained from observations and Day-3 forecast of the UM along with Mean Error (ME) over the Indian region for 2013, 2015 and 2018 is shown in the Figure 2. The boxes represent the area of study used for categorical verification. We have evaluated the rainfall for Day-1, Day-2 and Day-3 forecast but the results are shown only for Day-3 forecast for brevity. The monsoon seasons of 2013, 2015 and 2018 are chosen to highlight the improvement in mean rainfall forecast due to increasing the horizontal resolution and major model upgrades discussed in section 2.2. During JJAS of 2013 and 2015, the UM's horizontal resolution was N512 $(\sim 25 \mathrm{~km})$ and N768 $(\sim 17 \mathrm{~km})$ respectively while the dynamical core was upgraded from New Dynamics to ENDgame. Further, the model underwent increased horizontal resolution of N1280 ( 10km) during JJAS 2018. Although, we have evaluated the rainfall forecast for earlier seasons during 2007-2012 also, but no significant change is found over WGs and NE-states compared to N512 in capturing the monsoon rainfall.

As discussed, forecasting of rainfall in the tropics and Indian region, especially over the mountainous regions of WGs and NE-states, is always a challenge. However, the NWP models 
Geosci. Model Dev. Discuss., https://doi.org/10.5194/gmd-2019-65

Manuscript under review for journal Geosci. Model Dev.

Discussion started: 6 May 2019

(c) Author(s) 2019. CC BY 4.0 License.

are capable of capturing the large-scale features, but again these models also fail to pick up the fine scale features on many occasions. The UM Day-3 forecasts successfully predict the mean high rainfall amounts along WGs with a reducing rainfall eastwards over the peninsular India, while for rainfall over the NE-states, the model consistently shows over prediction during the monsoon seasons of 2013, 2015 and 2018. This is quantified in terms of ME showing a wet bias in the NE-States (extreme right panel Figure 2c, 2f, 2i). This wet bias has also been observed in other monsoon seasons. The model shows a large wet bias in rainfall over the Indo-Gangetic region adjoining the Himalayas during JJAS 2013, which is improved after 2013 as seen during the monsoon seasons of 2015 and 2018. One of the possible reasons for the improvement in the rainfall forecast over the Indo-Gangetic plains is the reduction in the UM bias for too strong easterlies at $850 \mathrm{hPa}$ (Iyengar et al., 2011) (Please see S2).

\subsection{Evaluation of Peak rainfall Forecast during recent years}

The highest rainfall of the monsoon season of 2013, 2015 and 2018 at each grid point over the Indian regions is shown in Figure 3 from observed and model Day-3 rainfall forecasts. The top panel shows the observed highest daily rainfall during respective seasons (Figure $3 \mathrm{a}, \mathrm{b}$ and $\mathrm{c}$ ) while the bottom panel shows the Day-3 highest rainfall predicted by UM (Figure 3d, e and f). During JJAS 2013, UM in Day-3 forecast fails to achieve the highest rainfall of the season (Figure 3d) as compared to observed peak rainfall (Figure 3a) over the WGs. This is substantially improved in 2015 and 2018 monsoon seasons as evident in the Figure (3b, e) and Figure (3c, f). Although, the model also shows some false alarms in this region, it consistently retains the peak amount of rainfall in Day-3 forecasts over the NE-states. Figures 4 (a) and (b) show the rainfall counts $(>10 \mathrm{~cm} /$ day) in observations and Day-3 forecasts over WGs and NEstates. Over WGs, the number of counts consistently increased in Day-3 forecasts after 2011 and 
Geosci. Model Dev. Discuss., https://doi.org/10.5194/gmd-2019-65

Manuscript under review for journal Geosci. Model Dev.

Discussion started: 6 May 2019

(c) Author(s) 2019. CC BY 4.0 License.

255 it has reached closer to the observed counts in 2018 (Figure 4a). During 2008 and 2009, the

256 model over-predicts the counts of rainfall exceeding $10 \mathrm{~cm} /$ day. The number of counts has

257 increased over NE-states also except 2012 and 2013. The model gives an indication of over-

258 estimation in picking up these counts in the rest of these years (Figure 4b). The improvement in

259 mean rainfall (section 4.1) and highest rainfall is linked to the improved horizontal resolution in model and data assimilation system as well as the upgrade of the dynamical core from New Dynamics (ND) to ENDgame. Also, the revised physics package including the increase in entrainment rate in deep convection together with improvements to several other physical parameterization schemes lead to the improvement in the skill of UM rainfall forecast (Walters et al. 2017. Sharma et al 2017).

\subsection{Number of counts of rainfall exceeding $80^{\text {th }}$ and $90^{\text {th }}$ percentiles}

As discussed before, the $80^{\text {th }}$ and $90^{\text {th }}$ percentile thresholds correspond to entire period 2007 to 2018. For each monsoon season, we calculate the grid point counts exceeding these thresholds as shown in Figure 5(a) and (b). For NE, there are 475x122 grids and WG there are 403x122 grid point counts. It is evident in Figure 5(a) that the number of grid point counts of rainfall exceeding $80^{\text {th }}$ percentiles (CAT-1) is varying from 2000 to 4000 over WG. Similarly, over NEstates, this count varies from 1800 to 2500 . Similarly, for $90^{\text {th }}$ percentile threshold (CAT-2) the counts vary from 1100 to 2100 over WG and 500 to 1500 over NE. These counts form good sample sizes for evaluation the rainfall exceeding $80^{\text {th }}$ and $90^{\text {th }}$ percentiles.

\subsection{Rainfall forecast verification over WGs and NE-states using traditional verification metrics}

Figures 6 and 7 display the seasonal verification scores of four metrics (BIAS, POD, FAR and CSI) computed based on the $2 \times 2$ contingency table for two rainfall thresholds of CAT- 1 and 
Geosci. Model Dev. Discuss., https://doi.org/10.5194/gmd-2019-65

Manuscript under review for journal Geosci. Model Dev.

Discussion started: 6 May 2019

(c) Author(s) 2019. CC BY 4.0 License.

CAT-2 over WGs and NE-states respectively. Day-1, Day-2 and Day-3 forecast have been chosen for evaluation. It is evident from figures 6 and 7 that the prediction of orographic rainfall during the monsoon seasons of 2007 to 2018 has been improved up to Day-3 of the forecasts over both the regions of study for the chosen thresholds of CAT-1 and CAT-2. However, the seasonal CSI values show a decrease with increase threshold for Day-1 to Day-3 forecasts (Figures 6 and $7(\mathrm{j}-1)$ ). While analyzing the model's performance over both the mountainous regions, CSI has a higher magnitude over WGs compared to NE-states for CAT-1 and CAT-2 thresholds.

A consistent increase (decrease) in POD (FAR) for both the rainfall thresholds of CAT-1 and CAT-2 at all lead times clearly indicates the improvement in UM's performance in predicting heavy (CAT-1) and very heavy rainfall (CAT-2) events over both the regions affected by orographic rainfall (Figure 6(d-f) and 7 (d-f)). This indicates the hit rate has increased during these monsoon years at both the rainfall thresholds of CAT-1 and CAT-2. This increase in hit rate is due to more events being correctly predicted (Sukovich et al., 2014). Also, the reduction in FAR indicates the improvement in POD is also due to a more accurate forecast rather than a 'spurious' increase in the number of extreme forecasts being made. This confirms that the improvement in skill of rainfall forecast of UM during the twelve monsoon seasons is genuine and not an artifact of more extreme rainfall forecasts being issued or the choice of verification metrics.

The seasonal verification of frequency BIAS during JJAS 2007 to 2018 are presented in Figures 6 and 7 (a-c) over both the mountainous regions of WGs and NE-states respectively for Day-1 to Day-3 forecast. The model accurately predicts these events of CAT-1 and CAT-2 at all lead times during 2007 to 2018. Since the Bias Score does not provide any information about the 
Geosci. Model Dev. Discuss., https://doi.org/10.5194/gmd-2019-65

Manuscript under review for journal Geosci. Model Dev.

Discussion started: 6 May 2019

(c) Author(s) 2019. CC BY 4.0 License.

forecast accuracy, it is generally evaluated in conjunction with another verification score such as

Critical Success Index (CSI) which provide additional information (Ebert et al., 2003).

303

\subsection{Improvement in rainfall forecast : Extreme scores}

Although the traditional verification scores such as CSI discussed in previous sections depict an improvement in the UM global operational NWP forecasting system during recent years, it tends to zero for rare events due to its low frequency of occurrence. Consequently, the assessment of the skill of forecasting of such heavy rainfall events is problematic because of the rarity of such events. The verification using these categorical scores (e.g CSI, ETS, and POD) creates a misleading impression that rare events cannot be skillfully forecast irrespective of the forecasting system (Stephenson et al., 2008). To overcome the shortcomings of the traditional verification metrics in predicting rare events, Ferro and Stepheson (2011) proposed a new set of verification metrics named the Extremal Dependence Index (EDI) and Symmetric EDI (SEDI). These scores range from -1 to 1 with 0 measuring no skill and 1 measuring the perfect score. The main advantages in these verification metrics are their indepence of the base rate and the fact that they do not converge to trivial values even at high rainfall events (rare events). SEDI verification metrics for two thresholds of CAT-1 and CAT-2 during the twelve monsoon seasons are displayed in Figure 7 (a-c) and 8 (a-c) over WGs and NE-states at all lead times. It is clear from Figures 8 and 9 that the skill of the model has improved in predicting heavy rainfall (CAT-1) and very heavy rainfall events (CAT-2) during the recent monsoon seasons and at all forecast lead times. Also, the magnitude of SEDI is higher compared to traditional verification metrics (CSI) used in the previous section. Some of the recent improvement in the UM rainfall forecast over the mountains can be attributed to increased horizontal resolution along with improved physics schemes and data assimilation. A significant improvement is also evident from 2007 to 2008 . 
Geosci. Model Dev. Discuss., https://doi.org/10.5194/gmd-2019-65

Manuscript under review for journal Geosci. Model Dev.

Discussion started: 6 May 2019

(c) Author(s) 2019. CC BY 4.0 License.

This improved skill is due to the upgrades in data assimilation system which had a full implementation of perturbed forecast physics convection, soil moisture nudging and increase

326 vertical range of GPSRO data assimilation.

\section{Summary and Conclusions}

During the monsoon season, heavy rainfall events over the orographic regions of WGs and NEstates of India pose a great challenge to accurate prediction using NWP models. This is mainly due to the medium and coarser grid resolution models, which fail to accurately resolve the orographic features and related meteorological processes. While increased grid resolution improves heavy rainfall prediction, it often leads to forecasting excessive and unrealistic rainfall associated with the mountains. The work reported in this paper evaluates and documents the improved skill in the Met Office Unified Model (UM) operational global NWP rainfall forecasts over the hilly regions of India during the monsoon seasons of 2007-2018. The changes in the operational UM during 2007-2018 include improvements in the representation of physical processes, improved dynamics and increased grid resolution from about $50 \mathrm{~km}$ in 2007 to $10 \mathrm{~km}$ in 2018. It is rather crucial to identify and quantify the impact of improved grid resolution in improved skill of the forecast model in predicting the heavy rains over hilly regions which are responsible for flash floods and landslides.

Evaluation results show that UM forecasts successfully capture all the large-scale monsoon rainfall features. The typical high rainfall amounts along the WGs and reducing rainfall amounts eastwards over the Indian peninsula is realistic. Similarly, high rainfall amounts over the North Eastern States with progressively reduced amounts westwards are also accurate. Evaluation suggests some of the following significant improvements during 2007-2018. 
Geosci. Model Dev. Discuss., https://doi.org/10.5194/gmd-2019-65

Manuscript under review for journal Geosci. Model Dev.

Discussion started: 6 May 2019

(c) Author(s) 2019. CC BY 4.0 License.

- The large wet bias over northern India adjoining the Himalayas during 2013 is significantly reduced during JJAS 2015 and 2018.

- The highest observed rainfall amounts over WGs $(>10 \mathrm{~cm} /$ day) are completely missed in the forecasts during JJAS 2013. Following improved grid resolution and move to ENDGAME dynamical core in 2014 , both of which improved the synoptic variability in the UM forecasts, the observed peak rainfall amounts $(>10 \mathrm{~cm} /$ day and also $>20 \mathrm{~cm} /$ day $)$ are better predicted along the west coast of India during JJAS 2015 and 2018.

The verification carried out with focus on heavy (CAT-1; $>80$ th percentile) and very heavy rainfall (CAT-2; > 90th percentile) forecasts adopts a method that takes into account the spatial variations in climatological characteristics. The main conclusions are-

- Rainfall forecast for CAT-1 has been improved by 0.18 to 0.34 ( 0.14 to 0.23 ), 0.3 to 0.5 ( 0.25 to 0.37$)$ and 0.7 to 0.5 ( 0.75 to 0.62$)$ in the case of CSI, POD and FAR respectively from 2007 to 2018 over WGs (NE-states) in Day-3 forecast. Also, CSI, POD and FAR indicate an improvement from 0.1 to 0.24 (0.08 to 0.15$), 0.18$ to $0.38(0.15$ to 0.26$)$ and 0.81 to 0.61 (0.84 to 0.73 ) for CAT-2 over WGs (NE-states). Improved skill over the WG's is higher compared to that in NE-states.

- Further, verification metrics (SEDI) for extreme and rare events have also been computed. An increase in SEDI from 0.21 to 0.55 (0.10 to 0.33$)$ in Day-3 forecast has been noted over WGs (NE-states) in SEDI for CAT-1. The improvement in SEDI is quite impressive and is 0.19 to 0.51 ( 0.12 to 0.32 ) over WGs (NE-states) for CAT-2.

This study is based on the long record (2007-2018) of UM global model's real time rainfall forecasts over India to highlight the improved skill in heavy rainfall forecasts. More recently 
Geosci. Model Dev. Discuss., https://doi.org/10.5194/gmd-2019-65

Manuscript under review for journal Geosci. Model Dev.

Discussion started: 6 May 2019

(c) Author(s) 2019. CC BY 4.0 License.

high-resolution NWP models are being used in India for operational forecasts of heavy rainfall events. Global 12km grid deterministic (NCUM) and Ensemble (NEPS; 23 members) are operational at NCMRWF. These models are also being evaluated for each season (Ashrit et al 2018 ) based on the $0.25 \times 0.25$ grid IMD-NCMRWF merged (Gauge + Satellite) rainfall analysis

372 used in this study since higher resolution satellite-based products have biases over land and fail to capture heavy rains over land (Mitra et al., 2013). Very high resolution rainfall analysis based on all conventional rain gauges, DWR and Satellite is essential for systematic evaluation of the heavy rainfall forecasts over India.

\section{Code and Data Availability:}

377 The verification carried out in the present study uses Fortran Codes, R-Software and verification 378 package available in $\mathrm{R}$. The observed daily rainfall data and the codes used in the study is available at $\underline{\mathrm{ftp}} / / / \mathrm{ftp} . n \mathrm{cmrwf} . g o v . i n /$ pub/outgoing/kuldeep/GMED. National Center for Medium Range Weather Forecasting (NCMRWF) has an MoU with Met Office, Exeter. This Unified Model (UM) forecast data can't be shared as we do receive this dataset under the mutual collaboration. However, the UM data is available for registered users on TIGGE portal (https://apps.ecmwf.int/datasets/data/tigge/levtype=sfc/type=pf/)

\section{Author's Contribution:}

To bring the manuscript in the final form, KS and RA have designed the approach of evaluation of rainfall skill over the orographic regions of India. The analysis has been carried out by KS and SK. AKM is the one who has developed the observed rainfall (Merged product) used in this study. ENR and SM are the principal scientists for the collaboration between NCMRWF and Met Office. KS and SK have finalized the manuscript with contributions of all the authors. 
Geosci. Model Dev. Discuss., https://doi.org/10.5194/gmd-2019-65

Manuscript under review for journal Geosci. Model Dev.

Discussion started: 6 May 2019

(c) Author(s) 2019. CC BY 4.0 License.

\section{Acknowledgements}

This work and its contributor Sean Milton were supported by the Met Office Weather and Climate Science for Service Partnership (WCSSP) India as part of the Newton Fund.

\section{References}

Airey, M. and Hulme, M.: Evaluating climate model simulations of precipitation: methods, problems and performances. Progress in Physical Geography, 19, 427-448, 1995.

Ajayamohan, R.S., Merryfield, W. J., and Kharin, V.V.: Increasing trend of synoptic activity and its relationship with extreme rain events over central India. J. Clim., 23, 1004-1013, 2010.

Ashrit, R., Sharma, K., Dube, A., Iyengar, G.R., Mitra, A.K. and Rajagopal, E.N.: Verification of short-range forecasts of extreme rainfall during monsoon.Mausam,66, 375-386, 2015.

Ashrit, R. et al.: Performance of NCMRWF Unified Model during the South-West Monsoon 2017. Chapter 11, Monsoon A Report 2017, IMD Met Monograph: No.:ESSO/IMD/Synoptic Met./01(2018)/22, 2018.

Brown, A.R., Beare, R.J., Edwards, J.M, Lock, A.P., Keogh, S.J., Milton, S.F., and Walters, D.N.: Upgrades to the boundary layer scheme in the Met Office NWP model. Bound. Lay. Meteorol., 118, 117-132, 2007.

Brown, A., Milton, S., Cullen, M., Golding, B., Mitchell, J. and Shelly, A.: Unified Modeling and Prediction of Weather and Climate: A 25-Year Journey. Bull. Amer. Met. Soc., 93, 1865$1877,2012$.

Buizza, R., Richardson, D. S. and Palmer, T. N. Benefits of increased resolution in the ECMWF ensemble prediction system and comparison with poor-man's ensembles. Q. J. R. Meteorol. Soc., 129, 1269-1288, 2003.

Davies, T., Cullen, M. J. P., Malcom, A. J., Mawson, M. H., Staniforth, A., White, A. A. and Wood, N.: A new dynamical core for the Met Office's global and regional modeling of the atmosphere. Q. J. R. Meteorol. Soc., 131, 759-1782 2005.

Dube, A., Ashrit, R., Ashish, A., Sharma, K., Iyengar, G.R., Rajagopal, E.N. and Basu, S.: Forecasting the heavy rainfall during Himalayan flooding-June 2013.Wea .Cli. Exremes.,4,2234, 2014.

Ebert, E.E., Damrath, U., Wergen, W. and Baldwin, M.E.: The WGNE assessment ofshort-term quantitative precipitation forecasts. Bull. Amer. Met. Soc., 84, 481-492, 2003. 
Geosci. Model Dev. Discuss., https://doi.org/10.5194/gmd-2019-65

Manuscript under review for journal Geosci. Model Dev.

Discussion started: 6 May 2019

(c) Author(s) 2019. CC BY 4.0 License.

423

424

425

426

427

428

429

430

431

432

433

434

435

436

437

438

439

440

441

442

443

444

445

446
Edwards, J.M. and Slingo, A.: Studies with a flexible new radiation code Part I. Choosing a configuration for a large-scale model. Q. J. R. Met. Soc., 122, 689-719, 1996.

Ferro, C.A.T. and Stephenson, D. B.: Extremal dependence indices: improved verification measures for deterministic forecasts of rare binary events. Wea. Forecasting., 26, 699-713, 2011.

Flynn, W. J., Nesbitt, S. W., Anders, A. M., and Garg, P.: Mesoscale precipitation characteristics near the Western Ghats during the Indian Summer Monsoon as simulated by a high-resolution regional model. Q.J.R. Meteorol. Soc, 143, 3070-3084, 2017.

Froude, M., J. and Petley, D.,N.: Global fatal landslide occurrence from 2004 to 2016.Nat. Hazards Earth Syst. Sci., 18, 2161-2181, 2018.

Goswami, B.N., Venugopal, V., Sengupta, D., Madhusoodanan, M.S. and Xavier P.K.: Increasing trend of extreme rain events over India in a warming environment.Science.314,1442$1445,2006$.

Gregory, D. and Rowntree, P.R.: A mass flux convection scheme with representation of cloud ensemble characteristics and stability dependent closure.Mon. Wea. Rev., 118,1483-1506, 1990.

Gregory, D. and Allen, S. (1991). The effect of convective scale downdraughts upon NWP and Climate. Proc. $9^{\text {th }}$ AMS conf on NWP, Denver, USA, 122-123.

Gunnell, Y. (1997).: Relief and climate in South Asia: the influence of the Western Ghats on the current climate pattern of peninsular India. Int J Climatol. 17,1169-1182, 1997.

Hamill, T.M. and Juras, J.: Measuring forecast skill: is it real skill or is it the varying climatology? Q. J. R. Meteorol. Soc., 132, 2905-2923, 2006.

Iyengar, G., Ashrit, R., Dasgupta, M. M., Chourasia, M., Sharma, K., Prasad, V. S., Rajagopal, E. N., Mitra, A.K., Mohandas, S. and Harenduprakash, L.: NCMRWF \&UKMO Global Model forecast verification: Monsoon 2010. NCMRWF Research Report.NMRF/MR/02/2011, 2010.

Jolliffe, I.T. and Stephenson, D.B.: Forecast Verification: A Practitioner's Guide in Atmospheric Science, Second Edition (eds I. T. Jolliffe and D. B. Stephenson), John Wiley \& Sons, Ltd, Chichester, West Sussex, PO19 8SQ, UK, 2012.

Krishnamurthy, V. and Ajayamohan, R. S.: Composite Structure of monsoon low-pressure systems and its relation to Indian rainfall.J. Climate.,23, 4285-4305, 2010.

Lin, Y.L., Chiao, S., Wang, T.A., Kaplan,M.L., Weglarz, R.P.: Some Common Ingredients for Heavy Orographic Rainfall, Wea. Forecasting.,16, 633-660, 2001. 
Geosci. Model Dev. Discuss., https://doi.org/10.5194/gmd-2019-65

Manuscript under review for journal Geosci. Model Dev.

Discussion started: 6 May 2019

(c) Author(s) 2019. CC BY 4.0 License.

Martin, G.M., Milton, S.F., Senior, C.A., Brooks, M.E., Ineson, S., Reichler, T., Kim, J.: Analysis and Reduction of Systematic Errors through a Seamless Approach to Modeling Weather and Climate. J. Climate 23, 5933-5957, 2010.

Mecklenburg, S., Joss, J., and Schmid W.: Improving the nowcasting of precipitation in an Alpine region with an enhanced radar echo tracking algorithm.J. Hydrol. 239, 46-68, 2000.

Met Office,: ENDGame: A new dynamical core for seamless atmospheric prediction. Available at http://www.metoffice.gov.uk/research/news/2014/endgame-a-new-dynamical-core, 2014.

Mitra, A.K, Bohra, A.K, Rajeevan, M.N. and Krishnamurti, T.N.(2009). Daily Indian precipitation analyses formed from a merge of rain-gauge with TRMM TMPA satellite-derived rainfall estimates. J. Meteor. Soc. of Japan, 87A, 265-279.

Mitra, A.K., Momin, I.M., Rajagopal, E.N., Basu, S., Rajeevan, M.N. and Krishnamurti, T.N. (2013). Gridded daily Indian monsoon rainfall for 14 seasons: Merged TRMM and IMD gauge analyzed values. Journal of Earth System Science, 122(5),1173-1182

Murphy, A.H. (1993). What is a good forecast? An essay on the nature of goodness in weather forecasting. Wea. Forecasting., 8, 281-293.

Pai, D.S., Sridhar, L., Rajeevan, M., Sreejith, O.P., Satbhai, N.S., and B. Mukhopadhyay (2014). Development of a new high spatial resolution $\left(0.25^{\circ} \times 0.25^{\circ}\right)$ long period $(1901-2010)$ daily gridded rainfall data set over India and its comparison with existing data sets over the region. Mausum,65,1-18.

Panziera, L.,Germann, U., Gabella, M. and P. V. Mandapaka (2011). NORA-Nowcasting of Orographic Rainfall by means of Analogues. Q.J.R. Meteorol. Soc, 137, 2106-2123.

Parthasarathy, B., Munot, A. A. andKothawale, D. R. (1995). Monthly and seasonal time series for all India, homogeneous regions and meteorological subdivisions: 1871-1994, Res. Rep. $R R-065,113$ pp., Indian Institute of Tropical Meteorology, Pune, India.

Pattanaik, D. R. and Rajeevan, M.N.(2010). Variability of extreme rainfall events over India during southwest monsoon season.Meteorol. Appl.17, 88-104.

Rajeevan,M., Bhate, J., Kale, J. D. and Lal, B. (2006).High resolution daily gridded rainfall data for the Indian region: Analysis of break and active monsoon spells.Current Science, VOL. 91, NO. 3, pp. 296-306.

Rao, Y.P. (1976). Southwest monsoon; meteorological monograph, synoptic meteorology, No 1/1976, India Meteorological Department 
Geosci. Model Dev. Discuss., https://doi.org/10.5194/gmd-2019-65

Manuscript under review for journal Geosci. Model Dev.

Discussion started: 6 May 2019

(c) Author(s) 2019. CC BY 4.0 License.

Rawlins, F., Ballard, S. P.,Bovis, K.J., Clayton,A. M., Li,D., Inverarity,G.W., Lorenc,A.C. and Payne, T.J. (2007).The Met Office global four dimensional variational data assimilation scheme, Q. J. R. Meteorol. Soc., 133, 347-362

Roberts, N. (2008). Assessing the spatial and temporal variation in the skill of precipitation forecasts from an NWP model, Meteorol. Appl., 15, 163-169

Sharma,K., Ashrit, R., Bhatla, R., Mitra, A.K., Iyengar, G.R. and Rajagopal, E.N. (2017).Skill of Predicting Heavy Rainfall Over India: Improvement in Recent Years Using UKMO Global Model. Pure appl. geophys., 174,4241-4250.

Shepard D. :A two-dimensional interpolation function for irregularly spaced data. 'In Proceedings of the 23rd ACM National Conference, New York, USA, 27-29August 1968, 1968.

Sikka, D.R.: A Study on the Monsoon Low-Pressure Systems over the Indian region and their relationship with drought and excess monsoon seasonal rainfall.COLA Technical Report 217. USA. , 61pp, 2006

Smith, R.B., and Coauthors: Local and remote effects of mountains on weather: Research needs and opportunities. Bull. Amer. Meteor.78,877-892, 1997.

Stephenson, D.B., Casati, B., Ferro, C.A.T. and Wilson, C.A.: The Extreme Dependency Score: a non-vanishing measure for forecasts of rare events. Meteorol. Appl., 15, 41-50, 2008

Sukovich, E.M., Ralph, F.M., Barthold, F.E., Reynolds, D.W. and Novak, D.R.: Extreme Quantitative Precipitation Forecast Performance at the Weather Prediction Center from 2001 to 2011. Weather Forecast.,29, 894-911, 2014.

Walters, D., and Coauthors: The Met Office Unified Model Global Atmosphere 6.0/6.1 and JULES Global Land 6.0/6.1 configurations. Geosci. Model Dev., 10, 1487-1520, 2017

Webster S., Brown, A.R., Cameron, D. and Jones,C.P. :Improvements to the representation of orography in the Met Office Unified Model.Q. J. R. Meteorol. Soc., 126, 1989-2010, 2003

Wilks, D.S. (Eds.) :Statistical Methods in the Atmospheric Sciences. 3rd Edition. Elsevier, 676 pp., 2011

Wilson, C. : Review of current methods and tools for verification of numerical forecasts of precipitation. Technical Report WP2.1, UK Met Office, 2000.

Wood, N., and Coauthors : An inherently mass-conserving semi-implicit semi-Lagrangian discretization of the deep atmosphere global non-hydrostatic equations. Quart. J. Roy. Meteor. Soc., 140, 1505-1520, 2014 
Geosci. Model Dev. Discuss., https://doi.org/10.5194/gmd-2019-65

Manuscript under review for journal Geosci. Model Dev.

Discussion started: 6 May 2019

(c) Author(s) 2019. CC BY 4.0 License.

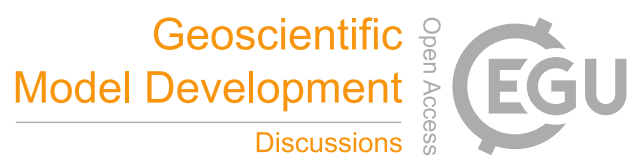

(c) (i)

524 Zhu, Y., Toth, Z., Wobus, R., Richardson, D. and Mylne.K.: The economic value of ensemble525 based weather forecasts. Bull. Am. Meteorol. Soc., 83, 73-83, 2002

526 Zhu, K., Yang, Y., and Ming, X.: Percentile-based Neighborhood Precipitation Verification and

527 Its Application to a Land falling Tropical Storm Case with Radar Data Assimilation. Adv. in 528 Atmos. Sc., 32, 1449-1459, 2015

529 
Geosci. Model Dev. Discuss., https://doi.org/10.5194/gmd-2019-65

Manuscript under review for journal Geosci. Model Dev.

Discussion started: 6 May 2019

(c) Author(s) 2019. CC BY 4.0 License.

Table 1. Some of the important Unified Model (UM) changes in recent years.

\begin{tabular}{|c|c|c|c|}
\hline \multirow[t]{2}{*}{ Year } & \multirow[t]{2}{*}{ UM Versions } & \multicolumn{2}{|l|}{ Configurations } \\
\hline & & Resolution and Data Assimilation System & Dynamical Core \\
\hline 2007 & $\begin{array}{l}\text { UM6.4 (Feb), UM6.5 } \\
\text { (July) }\end{array}$ & $\begin{array}{l}\text { N320L50 ( 40 km in mid-latitudes), } 12 \text { Minute time } \\
\text { step, 4D-VAR data assimilation }\end{array}$ & \multirow{8}{*}{ 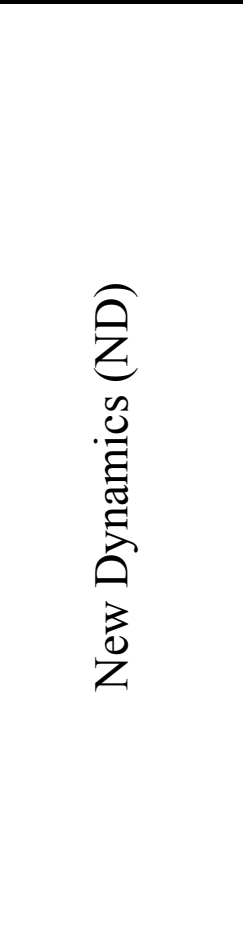 } \\
\hline 2008 & $\begin{array}{l}\text { UM7.0 (Mar), UM7.1 } \\
\text { (Aug) }\end{array}$ & $\begin{array}{l}\text { N320L50 ( } \sim 40 \mathrm{~km} \text { in mid-latitudes), } 12 \text { Minute time } \\
\text { step, 4D-VAR data assimilation }\end{array}$ & \\
\hline 2009 & $\begin{array}{l}\text { UM7.3 (Mar), UM7.4 } \\
\text { (Aug) }\end{array}$ & $\begin{array}{l}\text { N320L70 ( 40 km in mid-latitudes), } 12 \text { minute time step, } \\
\text { 4D-VAR data assimilation }\end{array}$ & \\
\hline 2010 & $\begin{array}{l}\text { UM7.6 (Apr), UM7.1 } \\
\text { (Aug) }\end{array}$ & $\begin{array}{l}\text { N512L70 ( 25 km in mid-latitudes), } 10 \text { minute time step, } \\
\text { 4D-VAR data assimilation }\end{array}$ & \\
\hline 2011 & $\begin{array}{l}\text { UM7.9 (Apr), UM8.0 } \\
\text { (Aug) }\end{array}$ & $\begin{array}{l}\text { N512L70 ( 25 km in mid-latitudes), } 10 \text { minute time step, } \\
\text { Hybrid 4D-VAR data assimilation }\end{array}$ & \\
\hline 2012 & $\begin{array}{l}\text { UM8.2 (Apr, PS29), } \\
\text { UM8.2 (Sept, PS30) }\end{array}$ & $\begin{array}{l}\text { N512L } 70 \text { ( } 25 \mathrm{~km} \text { in mid-latitudes), } 10 \text { minute time step, } \\
\text { Hybrid 4D-VAR data assimilation }\end{array}$ & \\
\hline 2013 & $\begin{array}{l}\text { UM8.2 (Jan , PS31), } \\
\text { UM8.2 (Apr, PS32) }\end{array}$ & $\begin{array}{l}\text { N512L } 70 \text { ( } 25 \mathrm{~km} \text { in mid-latitudes), } 10 \text { minute time step, } \\
\text { Hybrid data assimilation }\end{array}$ & \\
\hline \multirow{2}{*}{2014} & UM8.4 (Feb, PS33) & $\begin{array}{l}\text { N512L } 70 \text { ( } 25 \mathrm{~km} \text { in mid-latitudes), } 10 \text { minute time step, } \\
\text { Hybrid 4D-VAR data assimilation }\end{array}$ & \\
\hline & UM8.5 (July, PS34) & $\begin{array}{l}\text { N768L } 70(\sim 17 \mathrm{~km} \text { in mid-latitude), } 7.5 \text { minute time step, } \\
\text { Hybrid 4D-VAR data assimilation }\end{array}$ & \multirow{5}{*}{$\begin{array}{c}\text { Even Newer } \\
\text { Dynamics for } \\
\text { General } \\
\text { Atmospheric } \\
\text { Modeling of the } \\
\text { environment } \\
\text { (ENDGame) }\end{array}$} \\
\hline 2015 & $\begin{array}{l}\text { UM 8.5(Feb, PS35) } \\
\text { UM 10.1(Aug, PS36) }\end{array}$ & $\begin{array}{l}\text { N768L } 70 \text { ( } \sim 17 \mathrm{~km} \text { in mid-latitude), } 7.5 \text { minute time step, } \\
\text { Hybrid 4D-VAR data assimilation }\end{array}$ & \\
\hline 2016 & $\begin{array}{l}\text { UM 10.2(Mar, PS37) } \\
\text { UM10.4 (Nov, PS38) }\end{array}$ & N768L70 ( $\sim 17 \mathrm{~km}$ in mid-latitude), 7.5 minute time step, & \\
\hline 2017 & UM10.6 (Jul, PS39) & $\begin{array}{l}\text { N1280L } 70(\sim 10 \mathrm{~km} \text { in Mid-latitude), } 4 \text { minute time step, } \\
\text { Hybrid 4D-VAR data assimilation }\end{array}$ & \\
\hline 2018 & $\begin{array}{l}\text { UM10.8 (Feb, PS40) } \\
\text { UM10.9 (Sep,PS41) }\end{array}$ & $\begin{array}{l}\text { N1280L } 70 \text { ( } \sim 10 \mathrm{~km} \text { in Mid-latitude), } 4 \text { minute time step, } \\
\text { Hybrid 4D-VAR data assimilation }\end{array}$ & \\
\hline
\end{tabular}


Geosci. Model Dev. Discuss., https://doi.org/10.5194/gmd-2019-65

Manuscript under review for journal Geosci. Model Dev.

Discussion started: 6 May 2019

(c) Author(s) 2019. CC BY 4.0 License.

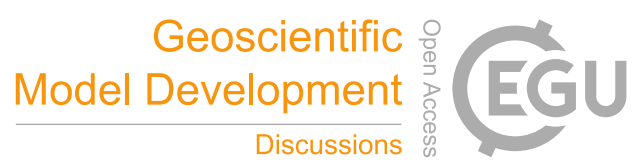

(c) (i)

531

532

\begin{tabular}{|c|c|c|c|c|}
\hline & & \multicolumn{2}{|c|}{ Observed } & \\
\hline & & Yes & No & Total \\
\hline \multirow{3}{*}{ Forecast } & Yes & Hits(a) & False alarms(b) & Forecast yes \\
\hline & No & Missed(c) & Correct negatives(d) & Forecast no \\
\hline & Total & Observed yes & Observed no & total \\
\hline
\end{tabular}


Geosci. Model Dev. Discuss., https://doi.org/10.5194/gmd-2019-65

Manuscript under review for journal Geosci. Model Dev.

Discussion started: 6 May 2019

(c) Author(s) 2019. CC BY 4.0 License.

(c) (1)

Table3. Categorical scores used in rainfall forecast verification in the present study

\begin{tabular}{|c|c|}
\hline NAME & ACRONYMS and DEFINITIONS \\
\hline BIAS & $B I A S=\frac{a+b}{a+c}$ \\
\hline Probability of Detection & $P O D=\frac{a}{a+c}$ also known as Hit Rate (H) \\
\hline False Alarm Ratio & $F A R=\frac{b}{a+b}$ \\
\hline Probability of False Detection & $P O F D=\frac{b}{b+d}$ or known as False Alarm \\
Rate (F)
\end{tabular}


Geosci. Model Dev. Discuss., https://doi.org/10.5194/gmd-2019-65 Manuscript under review for journal Geosci. Model Dev.

Discussion started: 6 May 2019

(c) Author(s) 2019. CC BY 4.0 License.

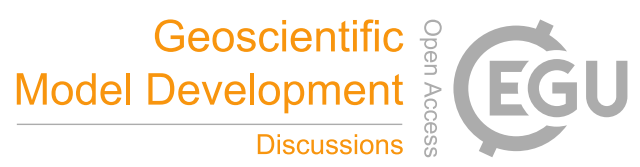

(c)

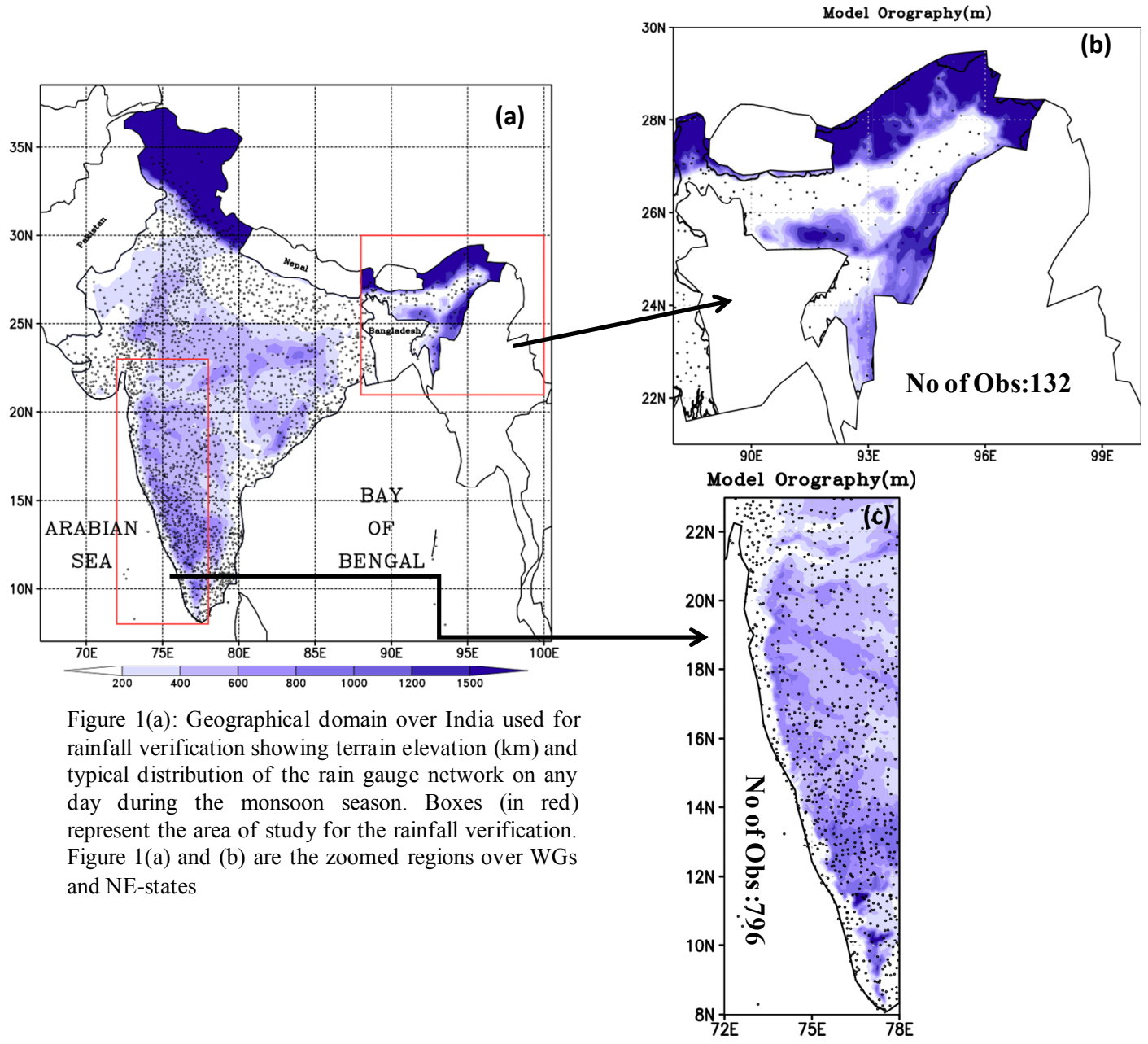


Geosci. Model Dev. Discuss., https://doi.org/10.5194/gmd-2019-65 Manuscript under review for journal Geosci. Model Dev.

Discussion started: 6 May 2019

(c) Author(s) 2019. CC BY 4.0 License.
Geoscientific Model Development

Discussions
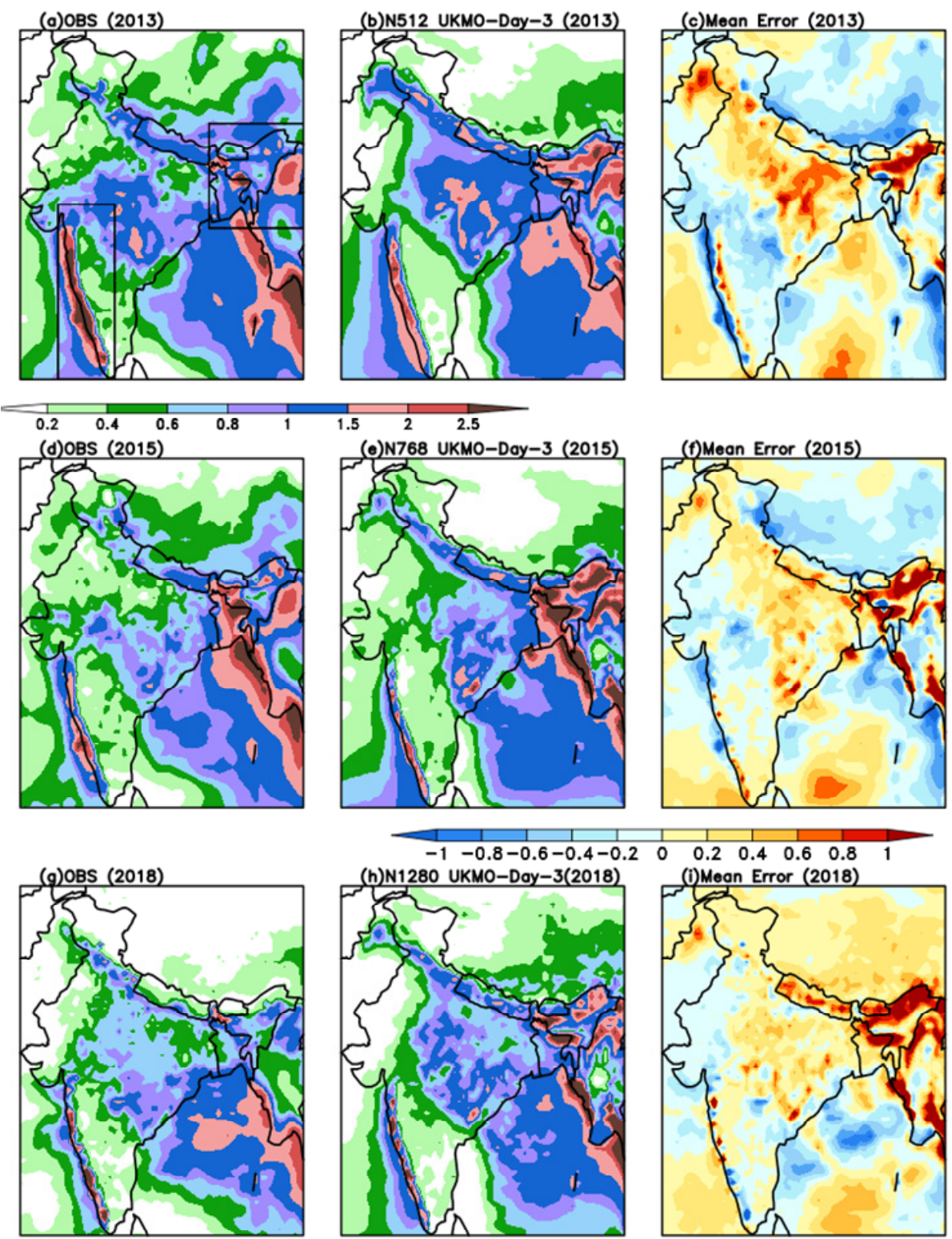

Figure 2. Observed (left panel), Day-3 Forecast mean rainfall (middle panel) and

Mean Error (right panel) in $\mathrm{cm} \mathrm{day}^{-1}$ over India during JJAS 2013, 2015 and 2018. 
Geosci. Model Dev. Discuss., https://doi.org/10.5194/gmd-2019-65

Manuscript under review for journal Geosci. Model Dev.

Discussion started: 6 May 2019

(c) Author(s) 2019. CC BY 4.0 License.

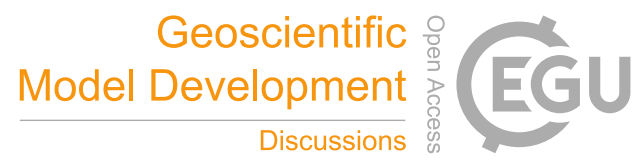

(c) (i)

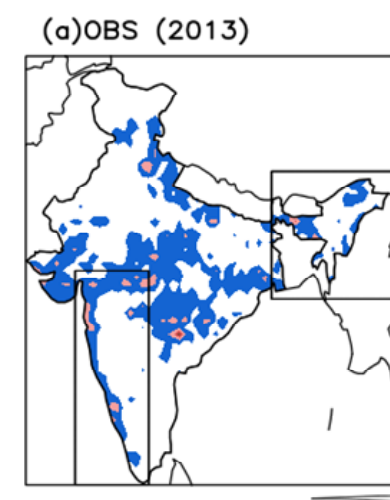

(b)OBS (2015)

(c)OBS (2018)

(d)UKMO Day-3(2013)
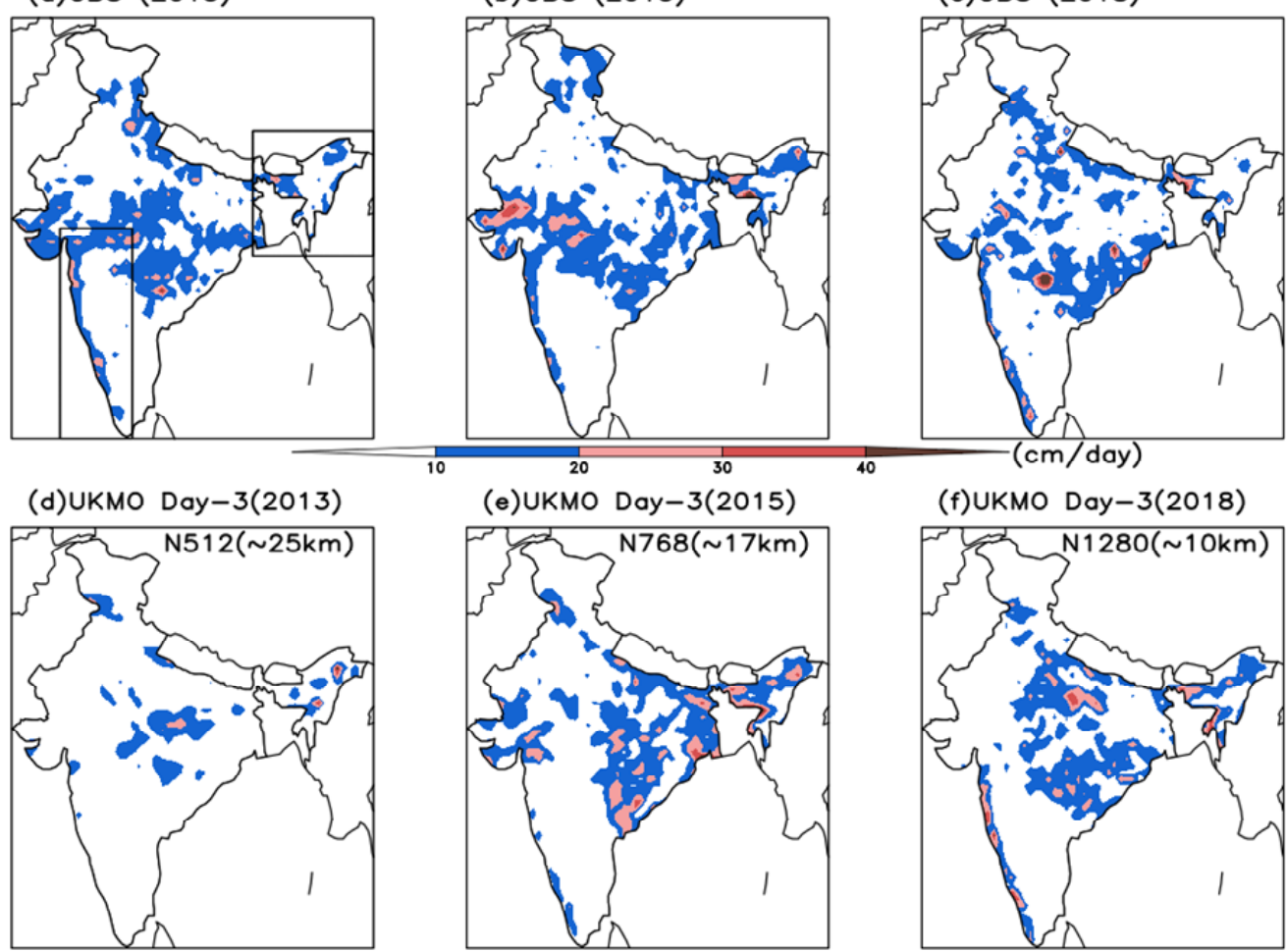

(e)UKMO Day-3(2015)
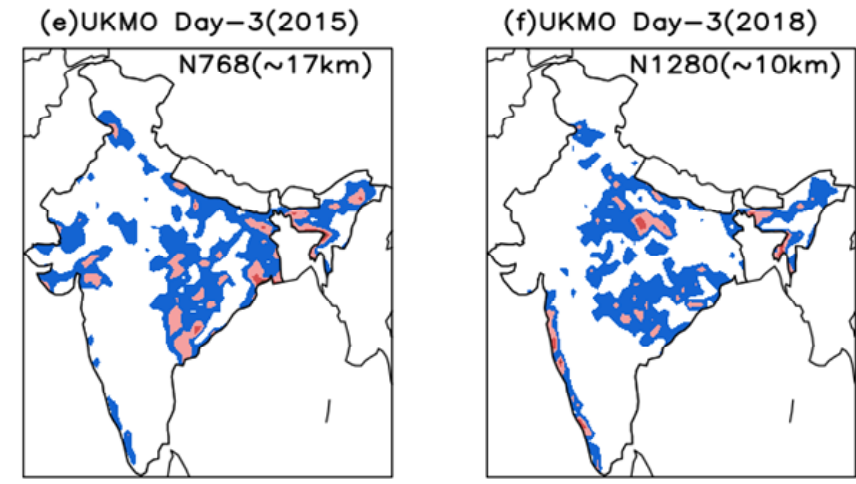

Figure 3. Observed (upper panel) and UKMO Day-3 highest rainfall Forecast (lower panel) at each grid point during JJAS 2013, 2015 and 2018 
Geosci. Model Dev. Discuss., https://doi.org/10.5194/gmd-2019-65

Manuscript under review for journal Geosci. Model Dev.

Discussion started: 6 May 2019

(c) Author(s) 2019. CC BY 4.0 License.
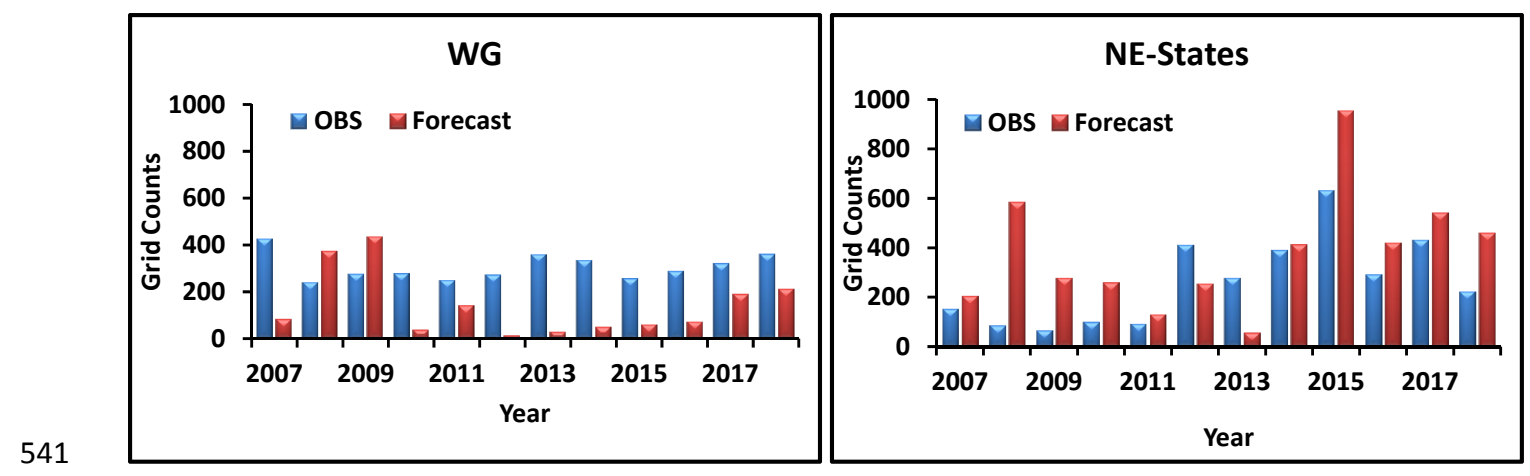

542

Figure 4. Number of counts in the observed and Day-3 forecast of rainfall threshold

543

of $10 \mathrm{~cm} /$ day over (a) WGs (b) NE-states 
Geosci. Model Dev. Discuss., https://doi.org/10.5194/gmd-2019-65

Manuscript under review for journal Geosci. Model Dev.

Discussion started: 6 May 2019

(c) Author(s) 2019. CC BY 4.0 License.

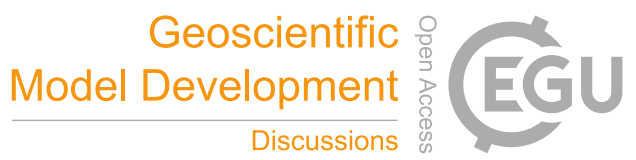

(c) (i)
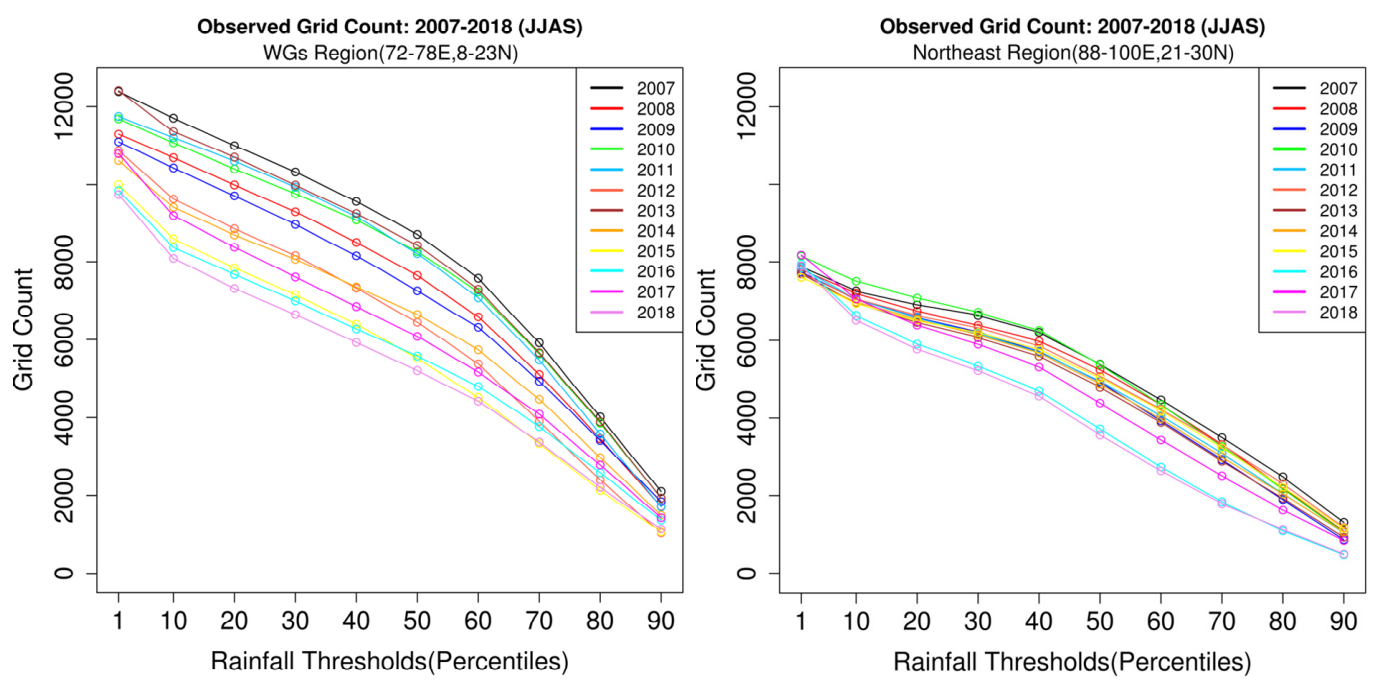

Figure 5. Observed rainfall counts over the WG and NE-states during JJAS 2007-2018. 
Geosci. Model Dev. Discuss., https://doi.org/10.5194/gmd-2019-65

Manuscript under review for journal Geosci. Model Dev.

Discussion started: 6 May 2019

(c) Author(s) 2019. CC BY 4.0 License.

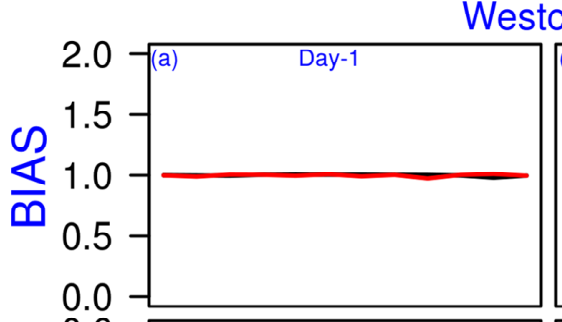

\section{Verification Scores}

Westcoast Region(72-78E,8-23N)
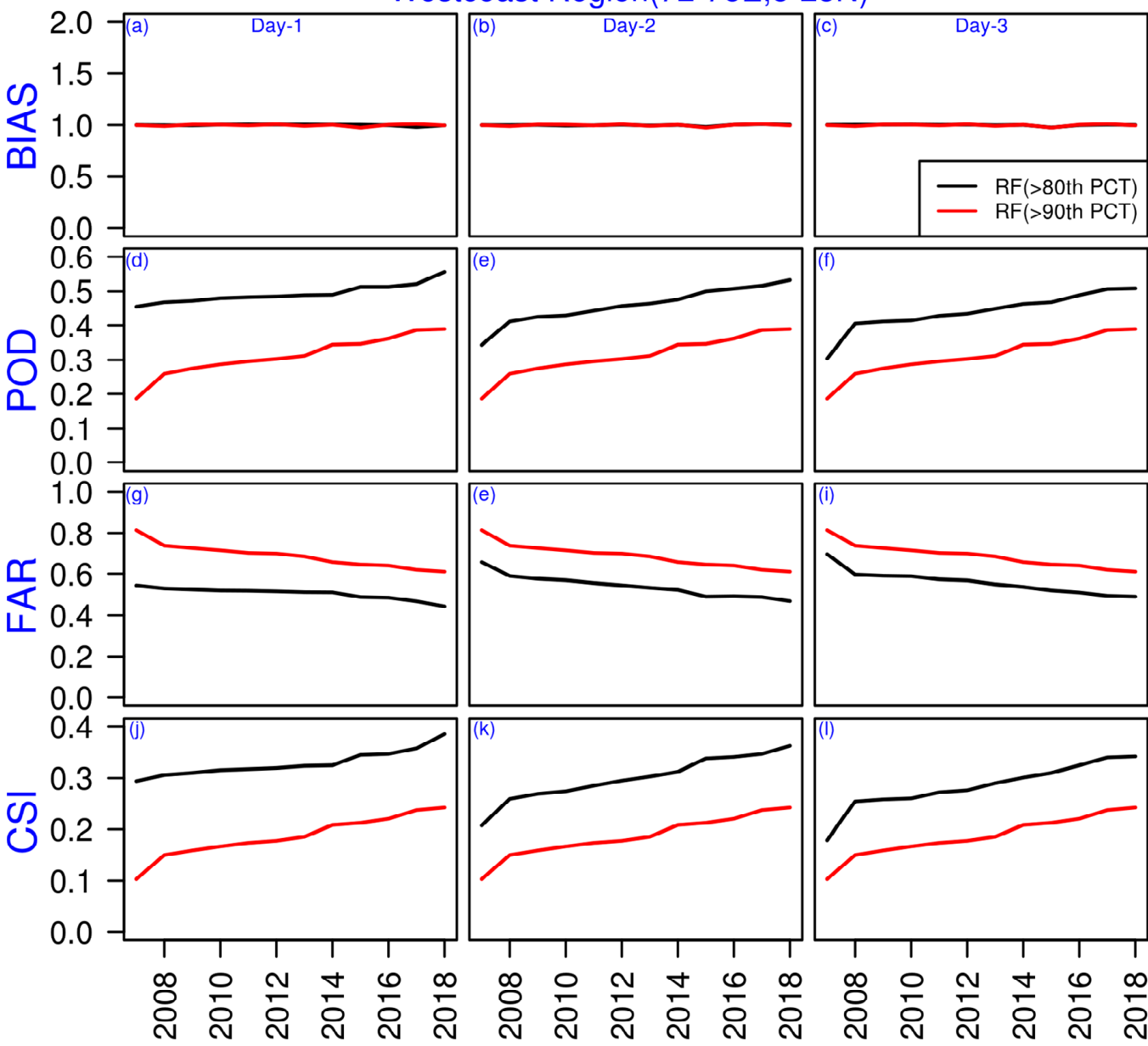

Figure 6. Bias (a-c), Probability of Detection (POD; (d-f)), False alarm Ratio (FAR;(g-i)) and Critical success index (CSI;(j-1)) computed for Day-1 Day-2 and Day-3 forecasts for CAT1 and CAT2 rainfall thresholds during JJAS 2007-2018 over WG . 
Geosci. Model Dev. Discuss., https://doi.org/10.5194/gmd-2019-65

Manuscript under review for journal Geosci. Model Dev.

Discussion started: 6 May 2019

(c) Author(s) 2019. CC BY 4.0 License.

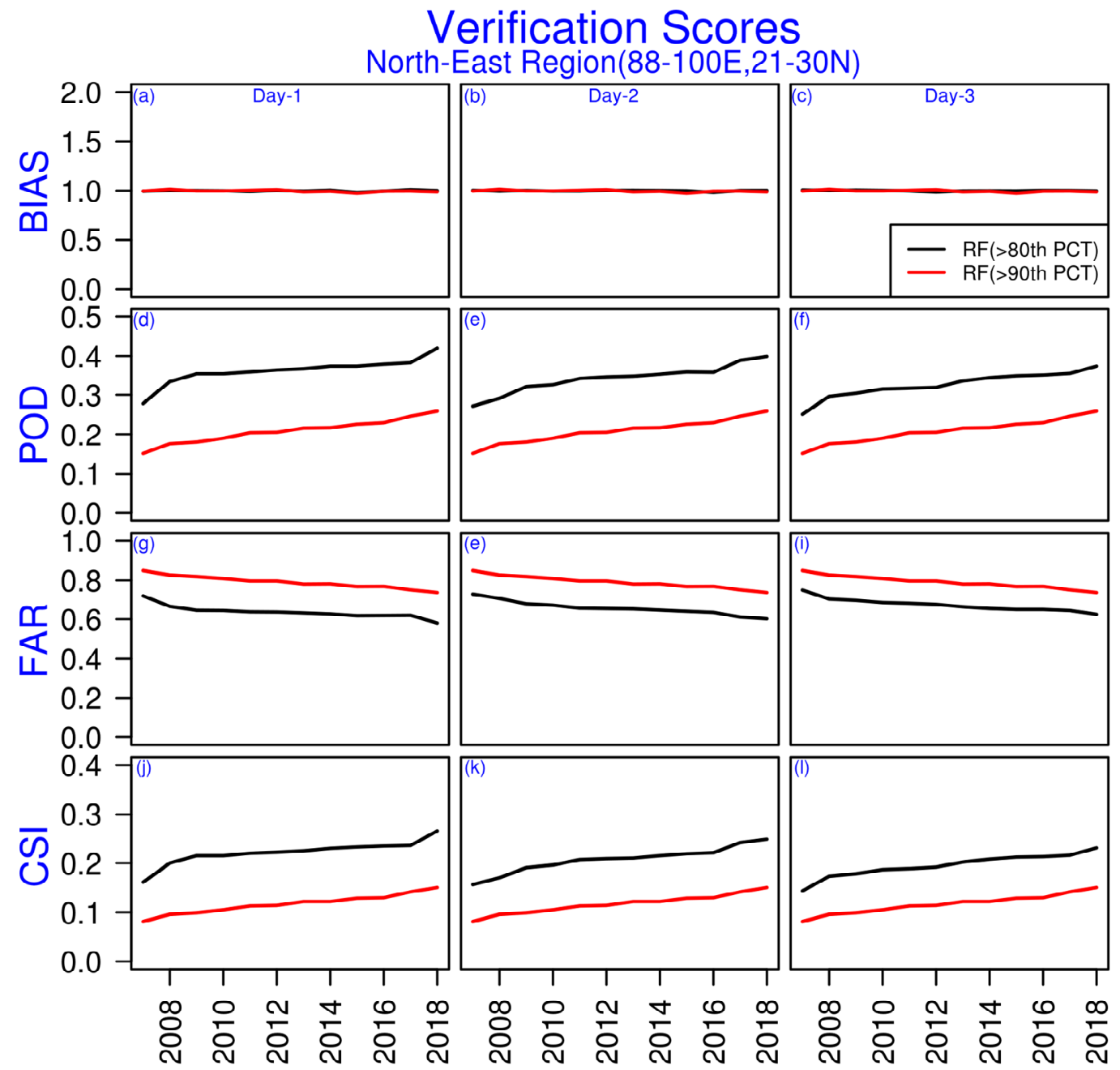

Figure 7. Bias (a-c), Probability of Detection (POD; (d-f)), False alarm Ratio (FAR;(g-i)) and Critical success index (CSI;(j-1)) computed for Day-1 Day-2 and Day-3 forecasts
over NE-states . 
Geosci. Model Dev. Discuss., https://doi.org/10.5194/gmd-2019-65

Manuscript under review for journal Geosci. Model Dev.

Discussion started: 6 May 2019

(c) Author(s) 2019. CC BY 4.0 License.

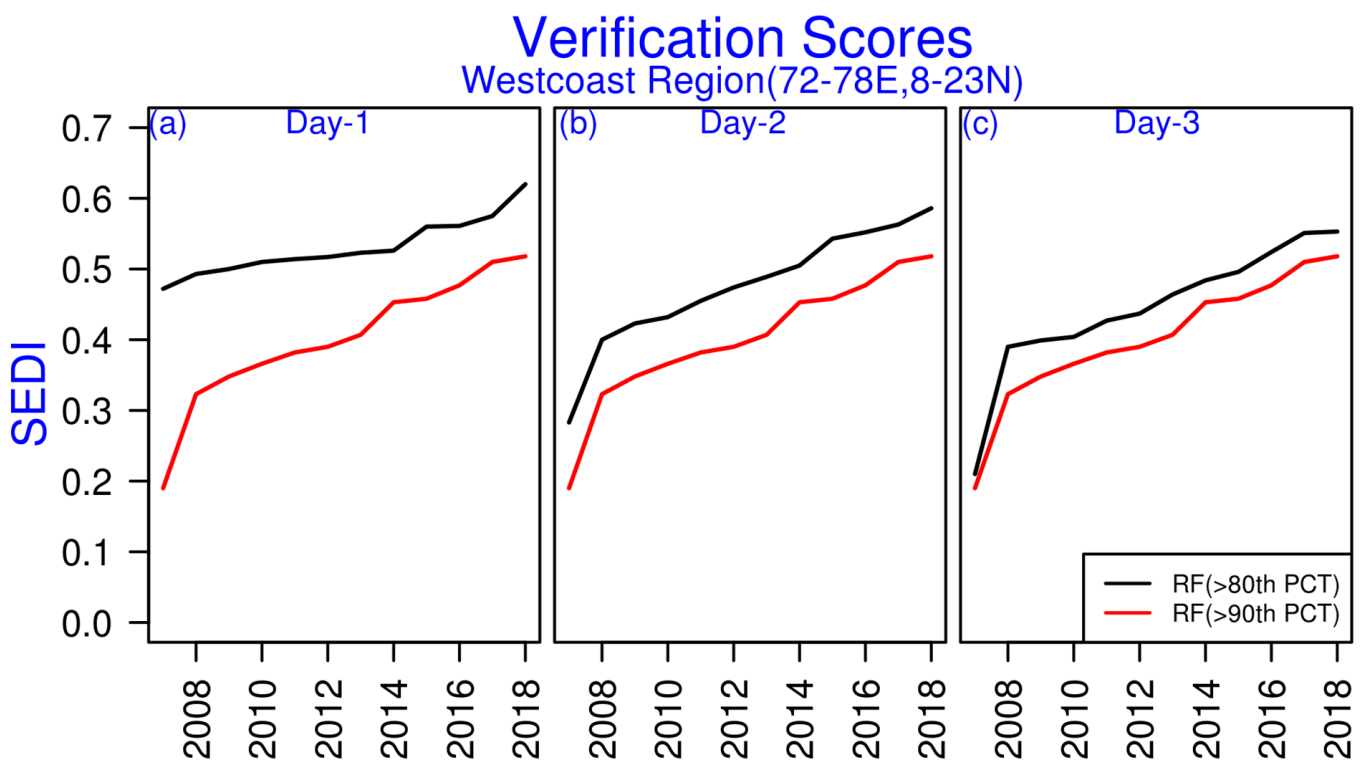

Figure 8. Symmetric extremal Dependence Index (EDI; (a-c))) computed for Day-1 Day2 and Day-3 forecasts for CAT1 and CAT2 rainfall thresholds during JJAS 2007-2018 over WG region 
Geosci. Model Dev. Discuss., https://doi.org/10.5194/gmd-2019-65

Manuscript under review for journal Geosci. Model Dev.

Discussion started: 6 May 2019

(c) Author(s) 2019. CC BY 4.0 License.

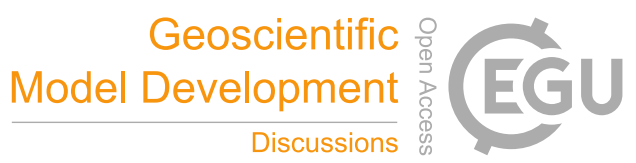

(c) (1)

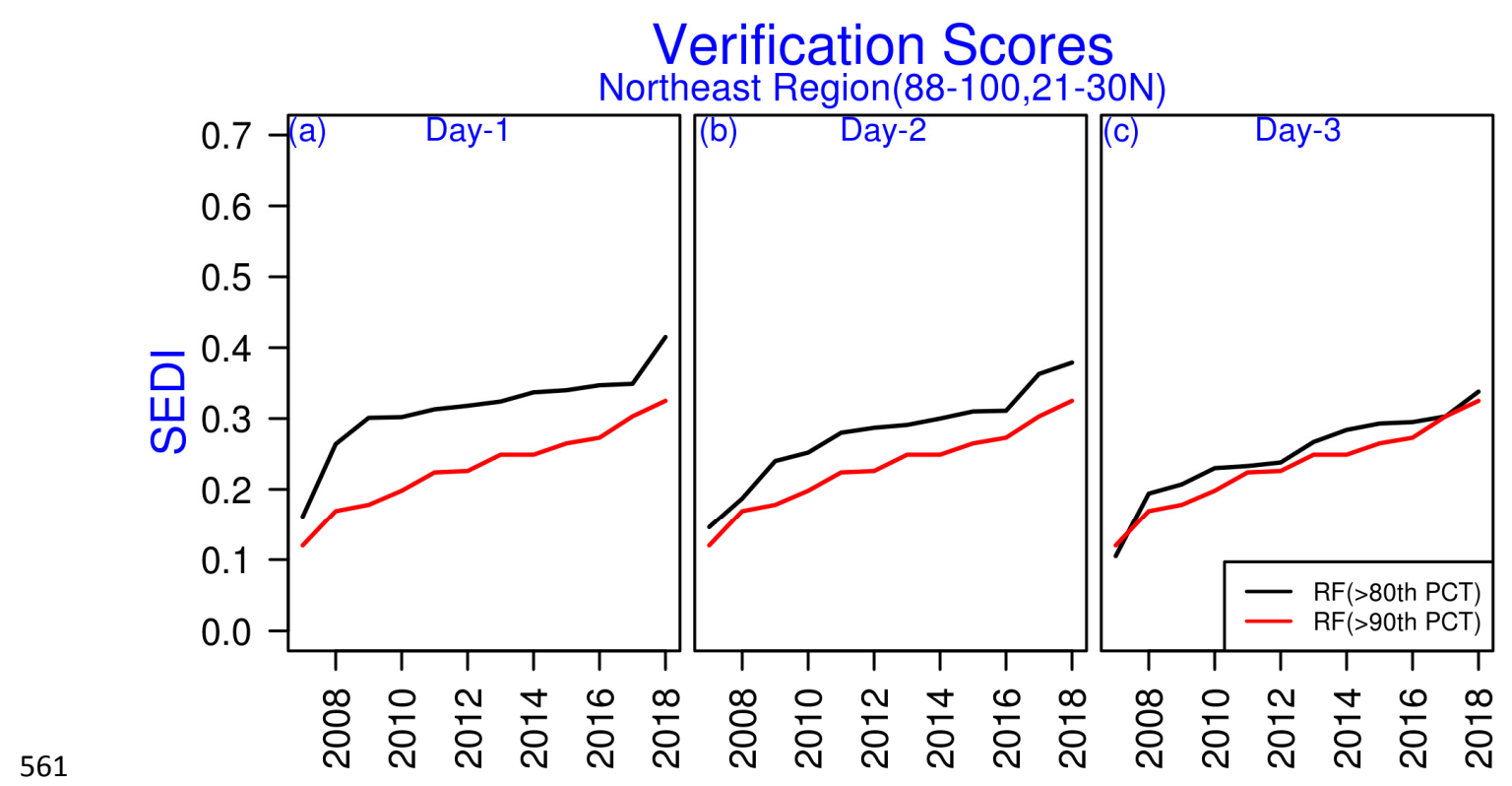

Figure 9. Symmetric extremal Dependence Index (EDI; (a-c)) computed for Day-1 Day-2 and Day-3 forecasts for CAT1 and CAT2 rainfall thresholds during JJAS 2007-2018 over NE-states 